\title{
THE IMPACT OF VIDEO- MAKING ACTIVITIES ON STUDENTS' GRAMMAR MASTERY
}

\author{
Nida Mufidah \\ Faculty of Tarbiyah and Teaching, Departement of English Education \\ IAIN Antasari Banjarmasin \\ Email: nidamufidah@iain-antasari.ac.id
}

\begin{abstract}
The teaching of grammar is frequently uninteresting so most of students are reluctant to learn this subject. Inviting them to learn the grammar by incorporating the use of technology may become a new way to attract their attention. In the present research, the writer conducted a research to compare the impact of grammar instructions on two classes, which used two different techniques to teach grammar: conventional method and video-making activities (VMA). There were 51 students of English Department at State Institute for Islamic Studies who participated in the research. The data were collected by using a test to measure their grammar mastery and a questionnaire to understand their respond toward the method. The result showed that the students who were taught by using the VMA had no better grammar mastery compared to those who were taught using the conventional method. However, the result of questionnaire yielded that most of the students agreed that the VMA was fun and interesting. This activity, according to them, also promoted creativity and technology literacy.
\end{abstract}

Keywords: Video-Making Activities (VMA), Experimental Study, Grammar Mastery,

\section{INTRODUCTION}

Grammar is inevitably an important subject for every language learners, especially for those who are projecting to be the teacher of the target language. Its mastery reflect your competence in in that language according to Swan (in Richard and Renandya, 2002). The ability to speak fluently and accurately is the standard to be called as a good foreign language speaker. Wang (2010) states that the term accurate commonly refer to a good and correct use of grammar. He said that mastering grammar is the foundation in the proficiency of a language and grammar teaching is an essential part of language teaching as well. It is due to the grammar takes part in all language skills teaching and learning. Like other language components, such as vocabulary and pronunciation, grammar is also integrated to those four language skills (Erdem and Celik, 2011). Therefore, the teaching and learning of grammar is necessary for English language learners.

Apart of its significant role, this subject is frequently not in the list of students' favorite subjects. When the writer interviewed one of grammar lecturer, she said that it is true that students seem easily get bored and are reluctant to learn grammar owing to its complexity. Based on her experiences, she told that some of students were fail on their grammar class. In the grammar II class, she found that 25 $\%$ of the students failed to pass the grammar test in the final exam. The most common problem faced by those students were they usually confused with the rules and the use 
of tenses. Besides, they sometimes felt that learning grammar were boring since they just read and listened to the explanation which mostly talk about patterns. If there was a discussion, again, it was full of topics on forms and rules.

To cope with that problem, teacher can apply several techniques such as by watching broadcast and streaming a video (Greenberg and Zanetis, 2012), through music and song (Kara and Aksel, 2013), using instructional program (Hani, 2014), extensive reading (Khansir and Deghhani, 2015), and so forth. Another technique which is interesting to be applied in the grammar class is one suggested by Harmer (2001). He mentions that for more advanced students, the teacher ask the students to make a "grammar lecture" task. The students are required to be in group to make their own grammar teaching video for their classmates. This video making activities is interesting because this activity can challenge the students to use their imagination and creativity to bring a fresh dimension to their learning.

There are several previous research related to the use of video for teaching. Mohammed (2013 )studied the effect of subtitled videos on grammar learning in an intermediate level ESL grammar classroom at a large state university in the U.S. Midwest. In the end of the study, he reported that through watching the subtitled video, the students could better understand the context that a specific grammar was used and they also had more positive attitude towards the grammar class. Besides, Ilin, Kutlu, \& Kutluay (2013) also explored the use of video for teaching grammar in an ESP class at a private language course in Iran. His study found that the use of video for teaching motivated the students to take parts in the lesson. The video also make the grammar more effective especially in term of time.

Seeing the effectiveness of the video, it inspires the writers to conduct the same research on video. She wants to investigate on the issue of effectiveness of video making activities (VMA) on students' grammar mastery. This issue needs to be explored since lack of research reports concerns on it in Indonesian context. Therefore, the research questions in the present research are: (1) Do the students who are taught using video making activities have better grammar mastery than those who are taught using conventional method?

\section{THEORITICAL REVIEW}

\section{The Teaching and Learning Grammar}

There are two polar approaches of teaching and learning grammar: inductive and deductive approach. By using inductive approach, someone draw a rules based on several examples of sentences given (Brown, 2007). According to Krashen (2009), inductive teaching argues that the best way to ensure learning is the students work out the rule themselves. Thus, when the students are asked to discover the form of the rules or practice precedes the explanation, it means the learnt inductively. This approach has some advantages and disadvantages.

Table 1 Advantages and Disadvantages of Inductive Approach

\begin{tabular}{|c|c|}
\hline Advantages & Disadvantages \\
\hline $\begin{array}{l}\text { Rules learners } \\
\text { discover for } \\
\text { themselves are } \\
\text { more likely to their } \\
\text { existing mental } \\
\text { structures than } \\
\text { rules they have } \\
\text { been presented } \\
\text { with. } \\
\text { The mental effort } \\
\text { involved ensures a } \\
\text { greater degree of } \\
\text { cognitive depth } \\
\text { which ensures } \\
\text { greater } \\
\text { memorability } \\
\text { Students are more } \\
\text { actively involved }\end{array}$ & 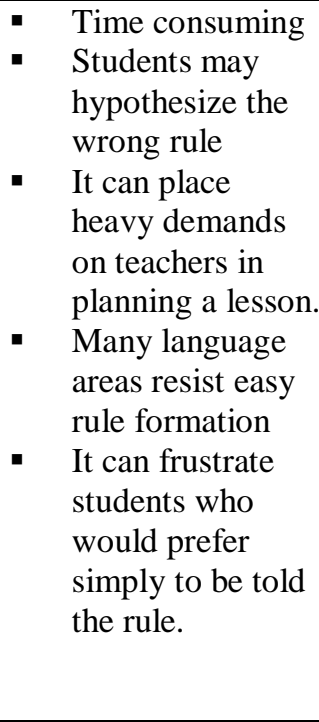 \\
\hline
\end{tabular}


in the learning

process,

- It challenges the

learners to

recognize the

pattern and solve a

problem.

- Learners get

opportunity for

language practice

- It prepares

students for greater

self-reliance and

autonomy

(Thornby, 1999)

The second approach is deductive which refers to the use of deductive reasoning in the teaching and learning process. Brown (2007) states that deductive reasoning is movement from a general to specific instances. It means that by using this approach the students are given the grammatical rules first, then they will learn the examples later on. This approach also has its advantages and disadvantages.

Table 2 Advantages and Disadvantages of Deductive Approach

\begin{tabular}{|c|c|}
\hline $\begin{array}{l}\text { Advant } \\
\text { ages }\end{array}$ & $\begin{array}{l}\text { Disadvant } \\
\text { ages }\end{array}$ \\
\hline $\begin{array}{l}\text { - It gets straight to } \\
\text { the point, and } \\
\text { can therefore } \\
\text { time saving } \\
\text { It respects the } \\
\text { intelligence and } \\
\text { maturity of many } \\
\text { students, and } \\
\text { acknowledges } \\
\text { the role of } \\
\text { cognitive } \\
\text { processes in } \\
\text { language } \\
\text { acquisition } \\
\text { It confirms many } \\
\text { students' } \\
\text { expectations } \\
\text { about classroom } \\
\text { learning } \\
\text { It allows the } \\
\text { teacher to deal } \\
\text { with language } \\
\text { points as they } \\
\text { come up. }\end{array}$ & $\begin{array}{l}\text { Straight the lesson } \\
\text { with a grammar } \\
\text { presentation maybe } \\
\text { unpleasant for } \\
\text { some students. } \\
\text { Grammar } \\
\text { explanation } \\
\text { encourages a } \\
\text { teacher-fronted, } \\
\text { transmission-style } \\
\text { classroom. The } \\
\text { teacher explanation } \\
\text { is often at the } \\
\text { expense of students } \\
\text { involvement and } \\
\text { interaction. } \\
\text { Explanation is } \\
\text { seldom as } \\
\text { memorable as other } \\
\text { forms of } \\
\text { presentation } \\
\text { It encourages the } \\
\text { belief that language } \\
\text { learning is simply a } \\
\text { case of knowing } \\
\text { the rules }\end{array}$ \\
\hline
\end{tabular}

(Thornby, 1999)

Those two approaches can be used along with many techniques and activities, including lecturing, having discussions, playing games, doing grammar exercises, or making video like what will be explained in the present research.

\section{Video Making Activities (VMA) and the Teaching of Grammar}

According to Harmer (2001: 290), video making activities is not only can provide a very telling feedback when the students can watch what they have made/ performed, but also can give a more realistic simulation. Furthermore. Video making activities also trigger students imagination and creativity to bring fresh dimension to their learning. He said that for more advanced students the teacher can set a grammar lecture task where group makes their own grammar teaching video for their classmates or lower level students. Harmer (2001) mentions several steps in video making activities:

1. It is started with the selection of the particular grammar topic. In this stage, the teacher can give them ideas about sources of the information for making their video.

2. The students do their research and discuss how to explain the grammar to a different group of learners.

3. The leader of the group or the teacher assigns different roles to each member to make sure that everyone actively participated in the video making process.

4. The students display the video to their classmates and teacher.

5. The teacher and classmates give feedback on the video.

It is also possible if the students upload their video into social media such Youtube so they can gain more feedback from the viewers. 


\section{METHOD}

\section{Research Design}

The present research is conducted to investigate the effectiveness of VMA on grammar mastery of the students. To measure the effectiveness precisely, the writer used experimental design. A quasiexperimental design is employed. It is due to the researchers do not have authority to select the sample randomly. Cohen, Manion, and Morrison (2007:282), state that quasi-experimental design is used since it is frequently not possible for researcher to make random selection or random assignment of schools and classrooms in educational research. Therefore, researcher here could only assign different treatments to two different classes (Latief, 2012:95).

The research design in this study used the one mentioned by Creswell (2012:307) that is quasi experimental posttest-only design. The use of posttest is to assess the differences between the two groups (Creswell, 2012:310). The variable measured in the posttest was the students' grammar mastery. The result of the posttest, then, was computed to see the difference between the mean scores of the experimental and the control groups.

The process of experimentation could simply be seen in the following table.

Table 3 Quasi-Experimental Posttest-Only Design

\begin{tabular}{lll}
\hline Group & Independent Variable & Post test \\
\hline E & $\mathrm{X}$ & $\mathrm{Y}_{2}$ \\
$\mathrm{C}$ & - & $\mathrm{Y}_{2}$ \\
\hline
\end{tabular}

Adapted from Creswell (2012)

Terms and symbols:

E : refers to Experimental group which practices the VMA.

C : refers to Control group which learn using conventional method.

$\mathrm{X}$ : refers to the treatment given in the Experimental group that is the implementation of VMA.

Y2 : refers to posttest in the form of grammar test.
Based on the Table 3, there are two research variables involved in this research, namely independent variable and dependent variable. The independent variable is the experimental treatment/manipulated variable which is treated, namely the implementation of VMA. Then other variable was dependent variable, i.e. the observed/measured variable, which the students' scores in the grammar test. It is expected that the result of computation on the difference between mean scores of the experimental and the control groups shows us whether the independent variable influences the dependent variable.

Treatment for the experimental group was making-video activity in which the students were asked to make a tutorial video in group. Meanwhile, for the control group, they got the same materials and same number of meetings but the difference was they were taught by using conventional method in which the teacher asked them to make a paper and to discuss it in the classroom.

The population in this research is the fourth semester students at English departments, Faculty of Tarbiyah and Teachers Training, IAIN Antasari Banjarmasin. There were five classes who took Grammar III, but the writers needed only two groups for the experimentation, she chose group A and B considering their equal English ability. The English department has classified the group based on a placement test for the students before they were accepted. Since both groups were assumed having equal ability so that there is no particular reason to decide which one becomes the experimental group and which one is the control group. Eventually, based on the result of lottery, the writer chose class A as the Experimental Group and B as the Control Group. Class A consisted of 29 students and class B consisted of 22 students.

Primary data were collected through a grammar test, which was given in the 
seventh meeting or at the middle test. It was administered to both experimental and control groups. Meanwhile, the secondary data was gained by using questionnaire to know the students responses towards the method used.The test was tried out in the beginning of the research.

Based on the result of validity test, there were 30 valid questions and the result of reliability test showed that the score was .888 , which meant that the test was reliable. Questionnaire was used to better understand the students' responses toward the teaching method. By giving the questionnaire, the writer could get in which points the students were happy or unhappy with the experimental teaching method. According to Latief $(2012 ; 148)$, an effective strategy is not only judged by the students high score but also the joyful classroom learning. Based on the purpose of this instrument, it was only the experimental group observed.

For the purpose of hypothesis testing, the researchers needed to fulfill the statistical assumptions to determine what types of test would be employed. Homogeneity, normality and linearity testings were conducted first. The criteria of acceptance or rejection of the assumptions in the present study was level of significance .05 ( $95 \%$ percent confidence).

When all of the assumptions are met, the researcher will use parametric statistical analysis to analyze the data. Parametric testing used in this study is independent-samples t-test, which is a data analysis system used to test the difference between two groups' means (Lodico, Spaulding, \& Voegtle, 2010:258). If it is not fulfilled, the researcher will use nonparametric statistical analysis to analyze the data. For the non-parametric analysis, the researcher will apply Mann-Whitney test, which is an analogue non-parametric procedure to independent sample t-test (McMillan, 1992: 204).

After that the hypothesis in this research will be tested tested by formulating the null hypothesis. The null hypothesis $\left(\mathrm{H}_{0}\right)$ is the students who practice their speaking through small talk activities have better speaking ability than those who do not. The post test scores are used to reject or not to reject $\mathrm{H}_{0}$. The criterion of rejection or acceptance is a level of significance .05 which is considered acceptable in field of education. The following figure shows the steps used by the researchers in hypothesis testing.

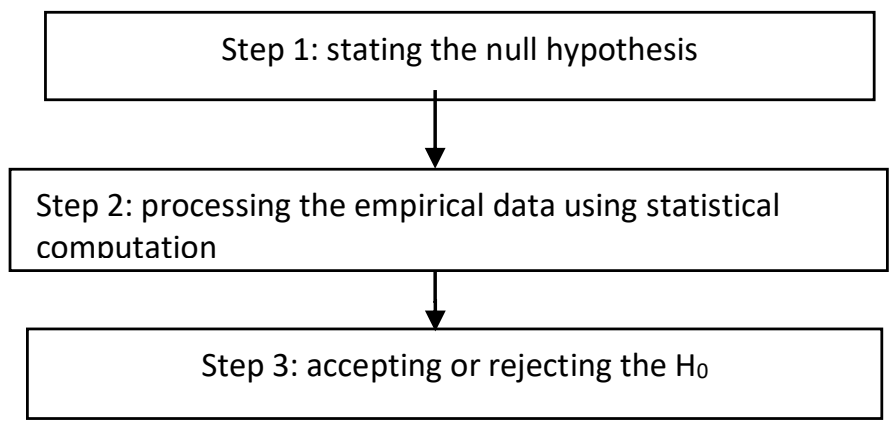

Figure 1 Steps in Hypothesis Testing

Next, the secondary data are gained from the result of questionnaire. The questionnaire reveals the data about students' opinions toward Small Talk technique. It would be analyze by categorizing the students' answers into positive, negative, and not clear opinions. Then the result will be presented in percentages so that the position of students' answers could be observed.

\section{FINGDINGS}

\section{The Students' Posttest Scores}

The main data in this study were the students' grammar test scores of Experimental and Control Group which were obtained from the posttest. After giving a different treatment to both groups for six meetings, posttest was administered in the seventh meeting. The treatment given to the Experimental group was VMA activity, while to the Control group was conventional method.

The posttest of the Experimental group was conducted on the same week, but 
different day based on the regular schedule of Grammar III class. It was conducted on Tuesday, November 13, 2016 for the Experimental Group and on Monday, November 6 for the Control Group. The result of posttest of both groups can be seen in Table 4.

Table 3 Descriptive Statistics of the Result of Posttest

\begin{tabular}{|c|c|c|c|c|c|c|}
\hline & $\mathrm{N}$ & $\begin{array}{c}\text { Mea } \\
n\end{array}$ & $\begin{array}{c}\text { Std. } \\
\text { Deviati } \\
\text { on }\end{array}$ & $\begin{array}{c}\text { Std. } \\
\text { Erro } \\
r\end{array}$ & $\begin{array}{c}\mathrm{Mi} \\
\mathrm{n} .\end{array}$ & $\begin{array}{c}\mathrm{Ma} \\
\mathrm{x} .\end{array}$ \\
\hline $\begin{array}{l}\text { Experime } \\
\mathrm{nt}\end{array}$ & $\begin{array}{l}2 \\
9\end{array}$ & $\begin{array}{r}73,8 \\
6\end{array}$ & 18,035 & $\begin{array}{r}3,34 \\
9\end{array}$ & 35 & 100 \\
\hline Control & $\begin{array}{l}2 \\
2\end{array}$ & $\begin{array}{r}73,5 \\
9\end{array}$ & 10,581 & $\begin{array}{r}2,25 \\
6\end{array}$ & 56 & 91 \\
\hline Total & $\begin{array}{l}5 \\
1\end{array}$ & $\begin{array}{r}73,7 \\
5\end{array}$ & 15,139 & $\begin{array}{r}2,12 \\
0\end{array}$ & 35 & 100 \\
\hline
\end{tabular}

Looking at a glance, the VMA activities seemed gave a better effect on the students' grammar mastery. However, this could not be claimed before the statistical hypothesis was done, especially when there was only small difference between those two groups. For further analysis to answer the research problem, a statistical analysis was conducted.

The first step needs to complete in the process of analyzing data for hypothesis testing is to carry out homogeneity, normality, and linearity testing as the fulfillment of the statistical assumptions. The data utilized for the fulfillment of statistical assumption were the primary data obtained from the result of the speaking posttest. The analysis was conducted using SPSS 20.0.

The result of analysis showed that the observed significance level or the $p$ value for homogeneity test was .042 for the students' grammar test score. It meant that they were not homogenous. Then, the result of normality testing showed that the calculated significance value (z-value) of the data obtained washigher than .05 $(.258>.05)$. Next, the result of linearity testing was .064. It meant that the observed significance level was greater than the significance level that the researcher used in this study, which is .05 .

Since the result showed that some of the data in homogeneity testing was not fulfilled so that the researcher is better to use non-parametric tests. The analysis used was Mann-Whitney.Based on the Table 5, we can see that the rank of method used for Experimental group was higher than the Control Group (26,45>25,41). However, the Asymp. Sig. value was higher than .05 which meant that $\mathrm{H}_{0}$ wasaccepted and $\mathrm{H}_{1}$ was rejected. Therefore, we can conclude that there was no significant effect of using VMA on students' grammar mastery.

Table 5 Mann-Whitney Test

\begin{tabular}{|l|r|r|r|r|}
\hline \multicolumn{1}{|c|}{ Group } & N & Mean Rank & Sum of Ranks \\
\hline \multicolumn{2}{|c|}{ Experimental } & 29 & 26,45 & 767,00 \\
Score & Control & 22 & 25,41 & 559,00 \\
& Total & 51 & & \\
\hline
\end{tabular}

Test Statistics ${ }^{a}$

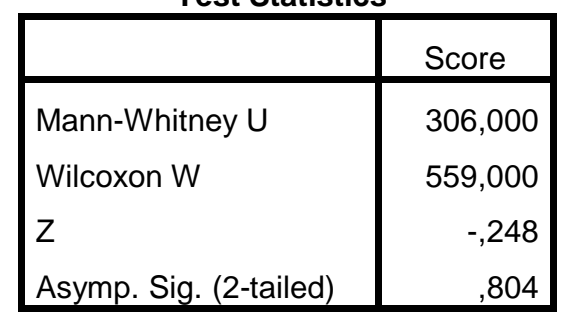

a. Grouping Variable: Group

In a nutshell, the finding showed that the students who were taught using the VMA had no better grammar mastery than those who were taught using the conventional method. 


\section{The Result Questionnaire of Students' Attitude toward the VMA}

The summary of the students' answers were presented in Table 5 .

Table 6. Students' Responses toward the VMA
VMA did not promote students to have better grammar mastery. It showed by their grammar test scores which was equal with the group taught by using the conventional method. The present finding was different with the previous findings made by Mohammed (2013) and Ilin, Kutlu, \& Kutluay (2013).

\begin{tabular}{|c|c|c|c|c|}
\hline \multirow{2}{*}{\multicolumn{2}{|c|}{ Variable }} & \multicolumn{3}{|c|}{ Students' Response } \\
\hline & & \multirow{2}{*}{$\begin{array}{l}\text { Positive } \\
82.14 \%\end{array}$} & \multirow{2}{*}{$\begin{array}{l}\begin{array}{l}\text { Not } \\
\text { Clear }\end{array} \\
7.14 \%\end{array}$} & \multirow{2}{*}{$\begin{array}{l}\text { Negative } \\
10.71 \%\end{array}$} \\
\hline & $\begin{array}{l}\text { General impression } \\
\text { towards the VMA }\end{array}$ & & & \\
\hline \multirow{4}{*}{\multicolumn{2}{|c|}{$\begin{array}{l}\text { 2. Good things of the } \\
\text { VMA } \\
\text { 3. Benefits of the VMA } \\
\text { 4. The weaknesses of } \\
\text { VMA } \\
\text { 5. Recommendation for } \\
\text { using the VMA }\end{array}$}} & $89.29 \%$ & $7.14 \%$ & $3.57 \%$ \\
\hline & & $46.43 \%$ & $17.86 \%$ & $35.71 \%$ \\
\hline & & $3.57 \%$ & $0 \%$ & $96.43 \%$ \\
\hline & & $50 \%$ & $32.14 \%$ & $17.86 \%$ \\
\hline \multicolumn{2}{|r|}{ Total } & $\begin{array}{l}267.86 \\
53.57 \%\end{array}$ & $\begin{array}{l}64.28 \\
12.86 \%\end{array}$ & $\begin{array}{l}167.85 \\
33.57 \%\end{array}$ \\
\hline \multicolumn{5}{|c|}{$\begin{array}{l}\text { In brief, the result of questionnaire } \\
\text { showed most of the students had positive } \\
\text { attitude towards this technique and they } \\
\text { also gained some benefits on improving } \\
\text { their speaking skill. Most of them said that } \\
\text { this technique really provoke their } \\
\text { creativity, especially in the process of } \\
\text { creating the video. It also engaged them } \\
\text { during the presentation since some of the } \\
\text { video had a very god visual and animation. } \\
\text { Some of students who loved the VMA also } \\
\text { stated that they get more knowledge on } \\
\text { technology when they prepared their } \\
\text { presentation. }\end{array}$} \\
\hline
\end{tabular}

\section{DISCUSSION}

This part presented the discussion of the result of data analysis presented above. It covered the discussion of the interpretation of the research findings and factors caused the ineffectiveness.

The result of final data analysis showed that the implementation of the
Mohammed's findings showed that

Total using video, the teaching and learning of 100 grammar become more effective. However, we also should note that in his research he 100ersed a subtitled video and the video was not made by the students themselves. They just $100 \%$ ownloaded from the internet source then presented in the classroom. This condition 100 was quite different with what the writers had done. They asked the students to make their own videos. As it is stated in the minor video was too fast so some of them get difficulty to comprehend the materials presented. This condition might affect the ineffectiveness.

Next, compared to Ilin, Kutlu, \& Kutluay (2013) research, the present research yielded the same result that the students were motivated to learn grammar by using videos. Ilin, Kutlu, \& Kutluay (2013) used the video as a self-study activity for the students meanwhile the present research used it as the main material discussed in the classroom presentation. The minor findings showed that $89.29 \%$ of the students got benefits from this activity and $46.43 \%$ of them said that the VMA was interesting, fun, and challenging.

Talking about the ineffectiveness, the result of students' responses toward the VMA might give some clues. According to $96.43 \%$ of the students, the VMA raised some problems such as it is a time consuming activity. They said that it took lots of time to produce the video and it also required lots of preparation in the classroom before the video could be presented. To overcome this problem, teachers or lecturers who are interested in adapting this activity would be better to findings, some students complained that the 
give enough training first for the students before asking them to perform this task. This help may make the preparation more effective so the students, especially the presenters, can spend more time on learning the grammar lesson.

The next problems are the speed of the video and the content. Some students felt that the speed is too fast so they cannot follow the explanation. Some said that the materials displayed were too simple considering the videos allowed were only five-minute videos. To deal with this problem, it is better to ask students to have a consultation with the lecturer before they present the video so that the lecturer can give feedback for the speed and the content. Asking students to give additional explanation after showing the video may also minimize this disadvantage.

Finally, the presenters become more passive and the students' tendency to enjoy the video effects, such as the music, the animation, etc. instead of understanding the materials also may contribute to the ineffectiveness of the VMA. A follow up activity should be designed to fix these problems. Adding interactive exercise as the content of the video can be a good solution. By having this activity, the students will not enjoy the video only, but they also can pay closer attention to the materials.

Besides those problems, we could not ignore the findings that the VMA also gave some advantages to students. Based on the result of the questionnaire, many students mentioned the benefits of the VMA. First, the VMA was interesting and fun. This finding supported what Harmer (2001) has said. He mentions that for more advanced students, video-making activities can challenge the students to use their imagination and creativity to bring a fresh dimension to their learning.

Second, it increased students' creativity and technology literacy. This kind of ability and literacy are quite important for students in $21^{\text {st }}$ century because of the demand of rapid global change (Greenberg \& Zanetis, 2012: 3). According to Greenberg and Zanetis (2012: 5 ), the use of video and multimedia technologies also give significant pedagogical impact, including interactivity with the content (the learners relates the materials to visual contents), engagement (the learners connect to visual content), and knowledge transfer and memory (the learners may remember and retain concepts better than other instructional media).

\section{CONCLUSION \& SUGGESTION}

Based on the result of statistical computation, it was found that there was no significant difference between the grammar mastery of the students' who were taught the video-making activities with those who were taught with the conventional method. It meant the null hypothesis in this study was accepted. It was not enough evidence to accept the hypothesis that the students who are taught the video-making activities had better grammar mastery than those who were taught without using that technique. Thus, based on this result, it could be concluded that the implementation of the video-making activities did not promote students to have better understanding of a grammar topic.

The ineffectiveness may be caused by several problems raised during the treatment. Many students claimed that the video-making activities were time consuming. Some of the videos made by the students were too fast so they could not follow the explanation. Some video were also too simple so they could not get comprehensive explanation of the topic. Last, some students enjoy seeing the video effects instead of understanding the content.

However, there were also some benefits of the video-making activities, such as it was more interesting and fun, it made students became more creative, and it promoted technology literacy. 
Regarding the results of this research, some suggestions are proposed. First, the suggestion goes to teachers/lecturers who want to use the VMA in the teaching and learning process. English teachers/ lecturers can adopt or adapt the VMA application used in the present research. However, they should notice some suggestions given for eliminating the problems raised during the treatment.

Next, the suggestiongoes to the future researchers. In the present research, we have found that some students have more than one learning styles. Since we just focus on the VAK learning styles, it will be better if the next researchers also take those combinations of learning styles into account so it will give a valuable contribution to the development of learning styles theory.

\section{REFERENCES}

Brown, H.D. (2007). Teaching by

Principles. New York: Pearson Education.

Covill, C. \& Jean, H. (2011). Learning styles. In: Supporting Learning in Practice SLIPConference, 13th April 2011, University of Huddersfield.

Craswell, J.W. (2012). Education Research: Palnning, Conducting, Evaluating Quantitative and Qualitative Research $4^{\text {th }}$ Edn. White Plains: Longman.

Greenberg, D. \& Zanetis, J. (2012). The Impact of Broadcast and Streaming Video in Education. California: Weinhouse Research.

Erdem, I \& Celik, M. (2011). Evaluation on Grmmar Teaching Methods.
International Periodical for the Languages, Literature, and History of Turkish or Turkic. Vol 6 (1), pp. 1030-1040.

Hani, N.A. B. (2014). The Effect of Using Computer in Teaching English Grammar to JordanianUniversity Students: The Passive Voice a Model. Journal of Educational \& Psychological Sciences, Vol. 15 (4), pp.659-680.

Harmer, J. (2001).The Practice of English Language Teaching.England: Pearson Education Limited.

Ilin, G., Kutlu, O., \& Kutluay, A. (2013). An Action Research: Using Video for Teaching Grammar in an ESP Class. Procedia: Social and Behavioral Sciences, Vol. 70, pp. 272-281.

Kara, Z.E. \& Aksel, A.S. (2013). The Effectiveness of Music in Grammar Teaching on Motivation and Success of the Students' at Preparatory School at Uludag University. Procedia: Sosial and Behavioral Sciences. Vol 106. Pp. 2739-2745.

Khansir A.A \& Deghhani, N. (2015). "The Impact of Extensive Reading on Grammatical Mastery of Iranian EFL Learners. Theory and Practice in Language Studies, Vol. 5 (7). Pp. 15011507.

Latief, M.A. (2012). Research Methods on Language Learning An Introduction. Malang: UM Press.

Lodico, M., Spaulding, D. \& Voegtle, K. (2010). Methods in Educational Research: From Theory to 
Practice, 2nd Edition. San

Francisco: Jossey-Bass

McMillan, J. H. (1992). Educational

Research: Fundamentals for the

Consumers. New York: Harper

Collins Publisher.
Mohammed, R.F. (2013). The

Effectiveness of Using Subtitled

Video to Teach Grammar.

Graduate Thesis. Iowa: Iowa

State University. 